\title{
Pathway to care among psychiatric patients attending a Tertiary care hospital in Kathmandu Valley
}

\author{
Rai N , Pokhrel P², Sharma PP ${ }^{3}$, Basnet $\mathbf{M}^{4}$ Dahal B ${ }^{5}$, Bista TB $^{5}$
}

1. Lecturer, Department of Psychiatry, Kist Medical College, Kathmandu 2. Lecturer, Department of Psychiatry, Kist Medical College, Kathmandu, 3. Professor \& Head, Department of Psychiatry, Kist Medical College, Kathmandu 4. Associate Professor, Department Of Psychiatry, BPKIHS, Dharan, Nepal 5. Intern, Kist Medical College, Kathmandu,

E-mail *Corresponding author : raineena15@gmail.com

\begin{abstract}
Introduction: Mental illness accounts for 14\% of all disability adjusted life years (DALYs) lost worldwide and is one of the major contributors to the global burden of disease. In spite of this much of burden and disability there is a huge gap between the treatment and help seeking behavior. Though, the mental illness is a common problem, due to stigma and lack of knowledge they prefer to visit alternative sources like faith healers, traditional practitioners and quacks. Very few of them seek psychiatrists help. So, this pathway to care study aims to provide some descriptive insight into the pathways to care among the psychiatric patients attending the tertiary care hospital in Kathmandu valley.
\end{abstract}

Material And Method: A cross-sectional study among 66 patients seeking psychiatric outpatient services in Kist medical College, Imadole, Lalitpur, Nepal which is a Teriatry hospital from the period of $1^{\text {st }}$ August - 31 $1^{\text {st }}$ October, 2018. Semi structured proforma developed by department of Psychiatry which covered the socio-demographic profile and WHO (1987) collaborative "pathway study" encounter form as a guiding tool was used to collect the data.

Results: Out of 66 enrolled patients, $60.6 \%$ were in the age group of 21-40. Almost equal proportion of male $(51.5 \%)$ and female (48.5\%) visited psychiatric services. Majority of the patients were married $(81.8 \%)$, Chhetri (25.8\%) by caste and Hindu (81.8\%) by religion. Majority of the patients were from outside valley (51.5), educated upto primary level (31.8\%) and housewife by occupation (28.8\%). The most common diagnosis was Depression $(16.7 \%)$ and Alcohol Dependence syndrome (16.7\%). Majority (45.5\%) of the patients had visited faith healer before visiting to Psychiatrists. $57.6 \%$ patient visited psychiatrists within 2.5 months duration and majority of them were initiated to visit psychiatrists by family members/ relatives.

Conclusion: Faith healers were the most common first contact for psychiatric patients. Despite of that majority of the patients had visited psychiatrists within 2.5 months duration. In most of the cases family members/relatives were the one to initiate for psychiatric consultation

Keywords: Pathway to Care, Psychiatry, Nepal

\section{INTRODUCTION}

Mental and behavioral disorders are found in people of all religions and all societies ${ }^{1}$ and are commonly associated with higher disability and burden than many physical illnesses. According to the World Health Organization (WHO), "it is estimated that globally 450 million people suffer from mental disorders." 2 Mental illness accounts for $14 \%$ of all disability adjusted life years (DALYs) lost worldwide and is one of the major contributors to the global burden of disease.3,4
In spite of this much of burden and disability there is a huge gap between the treatment and help seeking behavior. Though, the mental illness is a common problem, due to stigma and lack of knowledge they prefer to visit alternative sources like faith healers, traditional practitioners and quacks. Very few of them seek psychiatrists help. This pattern has been seen since long but with education and awareness scenario might change. So this study is conducted to see whether same pattern has been 
followed or trend has changed. The pathway a patient adopts to reach the appropriate treatment center is termed as the pathway of care. The information gained from this study can be used to further plan for more comprehensive and effective interventions to improve help-seeking behavior of people with mental illnesses.

\section{MATERIAL AND METHOD}

1. Study setting: Psychiatry outpatient department of Kist medical College, Imadole, Lalitpur, which is a tertiary Hospital.

2. Study period: $1^{\text {st }}$ August $-31^{\text {st }}$ October, 2018

3. Study design and sample: A cross-sectional study among 66 patients seeking psychiatric outpatient services in Kist medical College.

4. Study Criteria: patient of all ages and both gender attending to psychiatric outpatient services were included. Unwillingness to give consent for the study was excluded from the study.

5. Study measures and data collection: patient attending to psychiatric outpatient services who were willing to give consent were enrolled in the study. Written informed consents were obtained either from patient (who were able to give consent) or from family members. Whenever the patient was unfit to give consent, consent was taken from family members. Diagnosis was made by consultant Psychiatrist based on International Classification of Disease ICD-10 criteria. Semi structured proforma developed by department of Psychiatry which covered the socio-demographic profile and WHO (1987) collaborative "pathway study" encounter form as a guiding tool was used to collect the data. Ethical approval was taken from Institutional Ethical committee. Data were analysed using SPSS.

\section{RESULT}

Majority of the patients were in the age group of $21-40 \quad(n=40,60.6 \%)$. The mean age was 35.58(standard deviation 10.76). Almost equal proportion of male $(51.5 \%)$ and female $(48.5 \%)$ visited psychiatric services. The majority of the participants were married $(81.8 \%)$, Chhetri by caste $(25.8 \%)$ and Hindu by religion $(81.8 \%)$. Majority of the patients were from outside Kathmandu valley $(51.5 \%)$ and housewife by occupation (28.8\%).In regards to level of education $31.8 \%$ had primary education and one fourth $(25.8 \%)$ were illiterate.

Table 1: SocioDemographic profile of Patients

\begin{tabular}{|c|c|c|c|}
\hline Characterstics & Catagory & Frequency(n) & Percent(\%) \\
\hline \multirow[t]{5}{*}{ Age (in years) } & 20 or $<$ & 6 & 9.1 \\
\hline & $21-40$ & 40 & 60.6 \\
\hline & $42-50$ & 16 & 24.2 \\
\hline & $51-60$ & 2 & 3.0 \\
\hline & $\begin{array}{l}61 \text { and } \\
\text { above }\end{array}$ & 2 & 3.0 \\
\hline \multirow[t]{2}{*}{ Gender } & Male & 34 & 51.5 \\
\hline & Female & 32 & 48.5 \\
\hline \multirow[t]{8}{*}{ Caste } & Brahamin & 15 & 22.7 \\
\hline & Chhetri & 17 & 25.8 \\
\hline & Newar & 7 & 10.6 \\
\hline & Kirat & 2 & 3.0 \\
\hline & Tamang & 15 & 22.7 \\
\hline & Magar & 6 & 9.1 \\
\hline & Dalit & 3 & 4.5 \\
\hline & Gurung & 1 & 1.5 \\
\hline \multirow[t]{3}{*}{ Religion } & Hindu & 54 & 81.8 \\
\hline & Buddhist & 11 & 16.7 \\
\hline & Christian & 1 & 1.5 \\
\hline \multirow[t]{2}{*}{ Marital Status } & Married & 54 & 81.8 \\
\hline & Unmarried & 12 & 18.2 \\
\hline \multirow[t]{3}{*}{ Address } & Inside & 32 & 48.5 \\
\hline & valley & 34 & 51.5 \\
\hline & $\begin{array}{l}\text { Outside } \\
\text { valley }\end{array}$ & & \\
\hline \multirow[t]{5}{*}{ Education } & Illiterate & 17 & 25.8 \\
\hline & Primary & 21 & 31.8 \\
\hline & Secondary & 13 & 19.7 \\
\hline & Higher & 14 & 21.2 \\
\hline & $\begin{array}{l}\text { secondary } \\
\text { university }\end{array}$ & 1 & 1.5 \\
\hline \multirow[t]{6}{*}{ Occupation } & Student & 12 & 18.2 \\
\hline & Manual & 14 & 21.2 \\
\hline & worker & 8 & 12.1 \\
\hline & Business & 11 & 16.7 \\
\hline & Farming & 2 & 3.0 \\
\hline & $\begin{array}{l}\text { Teaching } \\
\text { Housewife }\end{array}$ & 19 & 28.8 \\
\hline
\end{tabular}


Table 2: Distribution of Subjects by Diagnosis

\begin{tabular}{|l|l|l|}
\hline Category & $\begin{array}{l}\text { Frequency } \\
(\mathrm{n})\end{array}$ & $\begin{array}{l}\text { Percent } \\
(\%)\end{array}$ \\
\hline Depression & 11 & 16.7 \\
Mania & 7 & 10.6 \\
Bipolar affective disorder & 8 & 12.1 \\
Ac Psychotic & 6 & 9.1 \\
ute and transient & 7 & 10.6 \\
Disorder & 6 & 9.1 \\
Schizophrenia & 6 & 9.1 \\
Psychosis not specified & 2 & 3.0 \\
Anxiety disorder & 2 & 3.0 \\
Dissociative Disorder & 11 & 16.7 \\
Somatoform disorder & & \\
Alcohol Dependence & & \\
Syndrome & & \\
\hline
\end{tabular}

The most common diagnosis among the study participants were Alcohol Dependence Syndrome and Depression (16.7\%) followed by Bipolar Affective Disorder (12.1\%) and Mania and anxiety disorder (10.6\%).

Table 3: Pathway To Care Characteristics:

\begin{tabular}{|c|c|c|c|}
\hline Characteristic & Category & $\begin{array}{l}\text { Frequency } \\
\text { (n) }\end{array}$ & $\begin{array}{l}\text { Percent } \\
(\%)\end{array}$ \\
\hline $\begin{array}{l}\text { Pathway to } \\
\text { first contact }\end{array}$ & $\begin{array}{l}\text { Faith healer } \\
\text { Psychiatrists } \\
\text { Medical } \\
\text { Personals other } \\
\text { than psychiatrist } \\
\text { Social worker }\end{array}$ & $\begin{array}{l}30 \\
19 \\
15 \\
2\end{array}$ & $\begin{array}{l}45.5 \\
28.8 \\
22.7 \\
3.0\end{array}$ \\
\hline $\begin{array}{l}\text { First } \\
\text { psychiatric } \\
\text { contact }\end{array}$ & $\begin{array}{l}10 \text { weeks } \\
11-20 \text { weeks } \\
21-30 \text { weeks } \\
31-40 \text { weeks } \\
>40 \text { weeks }\end{array}$ & $\begin{array}{l}38 \\
15 \\
3 \\
2 \\
8\end{array}$ & $\begin{array}{l}57.6 \\
22.7 \\
4.5 \\
3.0 \\
12.1\end{array}$ \\
\hline $\begin{array}{l}\text { Who initiated } \\
\text { the first } \\
\text { psychiatric } \\
\text { contact }\end{array}$ & $\begin{array}{l}\text { Police/court } \\
\text { Friends/neighb } \\
\text { or Family / } \\
\text { relatives On } \\
\text { their own }\end{array}$ & $\begin{array}{l}1 \\
17 \\
35 \\
13\end{array}$ & $\begin{array}{l}1.5 \\
25.8 \\
53.0 \\
19.7\end{array}$ \\
\hline
\end{tabular}

This study revealed that thirty patients $(45.5 \%)$ had visited to faith healer before coming in contact with Psychiatrists. Nineteen patients $(28.8 \%)$ had visited psychiatrists at first instance. Similarly, $22.7 \%$ had visited other medical personals (non psychiatrists).Only 3.0\% had visited social workers.
Majority of the patients (57.6\%) visited psychiatrists within < 10 weeks of duration followed by 11-20 weeks and > 40 weeks of duration amounting to $22.7 \%$ and $12.1 \%$ respectively. Most of them (53.0\%) were initiated by family members / relatives for psychiatric consultation. $25.8 \%$ were initiated by friends/neighbors. $19.7 \%$ were self referral.

\section{DISCUSSION:}

Overall findings from this cross-sectional study provide some descriptive insight into the pathways to care among the psychiatric patients attending the tertiary care hospital in Kathmandu valley.

In our study majority of the subjects seeking psychiatric care were those belonging to the age group of 21 to 40 years $(60.6 \%)$. This could be the fact that $21-40$ years is the economically productive age group so more attention was given to this age group. This findings keeps parallel with study from India. ${ }^{5}$ We have found that almost equal proportion of male $(51.5 \%)$ and female $(48.5 \%)$ patients seeking psychiatrists help. This findings is similar to the study by Anitha Jeyagurunathan et al. from Singapore. ${ }^{6}$ This is the positive findings for us where gender biasness has deep rooted since long. There was a preponderance of Chhetri caste followed by Brahamin and Tamang. Majority of the patients were Hindu $(81.8 \%)$ followed by Buddhist (16.7\%) by religion. This might be because of presence of large population of these religions in this locality. Other reason for being most of the patients Hindu might be due to the fact that Nepal being the Hindu country.

This study also noted that majority of the subjects were married (81.8 \%).This findings is in contrast with the study by Ibrahim et al. where majority $(57.9 \%)$ of the subjects were single. ${ }^{7}$ The reason for majority of the subjects being married could be because of the better support system due to availability of significant figures in their life.

Most of the subjects were from outside the valley. This reflects the fact that the people outside the valley also utilize the psychiatric services of this tertiary hospital. Almost one third of the subjects $(31.8 \%)$ were educated up 
to primary level and house wife $(28.8 \%)$ by occupation.

By diagnosis distribution our sample showed the most common diagnosis was Depression $(16.7 \%)$ and Alcohol dependence Syndrome (16.7\%) followed by Bipolar Affective Disorder $(12.1 \%)$.This findings is almost similar(expect Alcohol dependence syndrome) to a findings from India by Chandrakant lahariya et al. where mood disorder was predominant. ${ }^{8}$ western country by Umberto Volpe et al. where the most common diagnosis was Affective disorders. ${ }^{9}$

The reason for majority of patients with mood disorders and substance dependence sought help could be because of high level of social and occupational dysfunctions in individuals with mood disorders and alcohol dependence.

In the present study almost half $(45.5 \%)$ of the cases contacted faith healers as their first point of contact for treatment psychiatric illnesses. This finding is consistent with the study from India. ${ }^{6}$ However, this study is in contrast with the another study from India where majority of the cases contacted Psychiatrists at first instance. ${ }^{10}$ However, nearly one third of the cases sought help from Psychiatrists at first instance. It appears that initial help seeking behavior of these patients and their families were influenced by religious beliefs and misconceptions because of lack of awareness and stigma associated with mental illnesses. The variation in help seeking behavior for their mental illnesses may be because of level of understanding of the diseases.

This study revealed that most of the patients approached Psychiatric care within 2.5 months of onset of symptoms. This is the welcoming findings and a good indicator of health seeking behavior among patients with mental illnesses. This findings seem consistent with the findings of different studies from India. ${ }^{10,11}$ However, $12.2 \%$ of patients in this study took longer than 10 months to seek psychiatric care. The reason for delaying in seeking help from psychiatrists could be due to stigma associated with mental illnesses and lack of awareness leading them to look for alternative sources. This study didn't examine the reason for delay in help seeking behavior.
Majority (53\%) of the referral were by family and relatives. This shows that despite of disintegration in society family support in our society is still good.

Limitations: Few limitations of the current study include: 1 .The sample size is small. So this finding cannot be generalized to all patients seeking treatment in tertiary level hospital 2)This study did not examine the reason for delay in help seeking behavior and the reason for seeking help from other sources at first instance.

\section{CONCLUSION:}

The study found that the majority of the patients attending out-patient psychiatric service suffered from Depression, alcohol dependence syndrome followed by Bipolar Affective Disorder.

Though, faith healers were the most commonly sought primary helping agency among the study subjects interestingly majority of the patients sought help from psychiatrist within 2.5 months duration. This is the very welcoming findings. In majority of the cases family members were the one who initiated for the psychiatric help.

\section{ACKNOWLEDGEMENT: None}

\section{CONFLICT OF INTEREST: None}

\section{REFERENCES:}

1. Park K. Park's textbook of preventive and social medicine. 12th ed. Jabalpur: M/s Banarasidas Bhanot; 2009. P. 734.

2. WHO. The World Health report 2001: mental health: new understanding, new hope. Geneva: World Health Organization

3. Prince M, Patel V, Saxena S, Maj M, Maselko J, Phillips MR, et al. No health without mental health. Lancet 2007; 370:859877.

4. Mathers CD, Loncar D. Projections of global mortality and burden of disease from 2002 to 2030. Plos Med 2006; 3: e442.

5. Lokesh kumar et al. Delay in first psychiatric consultation and its reason. AP J Med 2011; 12 (2):7983.

6. Anitha Jeyagurunathan et.al. Pathways to care among psychiatric outpatients in a tertiary mental health institution in Singapore. International Journal of social Psychiatry .2018, vol. 64(6) 554-562.

7. Brahim I et al pathway to psychiatric care for mental disorders: a retrospective study of patients seeking 
mental health services at a public psychiatric facility in Ghana. Int J ment Health Syst (2016) 10:63).

8. Lahariya $C$ et al. Pathway to care among psychiatric patients attending a mental health institution in central India. Indian J Psychiatry 2010;52: 333-8)

9. Umberto et al. Pathways to Mental health care in Italy: Results from a multicenter study. International journal of social Psychiatry 2014, vol. 60(5) 508-513.

10. Gupta Dk et al. Help seeking behavior and pathways to care among patients seeking treatment at a private psychiatric hospital in North India. J Mental Health Hum Brhav 2018; 23: 63-6

11. Behari $m$, Gupta Dk, Singh v, Verma KK, Sengupta $S N$, Sidana $R$, et al. Help seeking behavior and pathways to care among patients seeking care at a community mental health clinc and psychiatry outpatients department of medical college: A study from North Rajasthan. J Ment Health Hum, Behav 2013:18:18-33. 